\section{Determinants of Entrepreneurial Intentions in ICT Industry: Gender and country of origin perspective}

\author{
Mirjana Pejić Bach \\ Faculty of Economics \& Business, University of Zagreb, Croatia \\ mpejic@efzg.hr
}

\section{Marjana Merkač Skok}

Faculty of Entrepreneurship, Gea College, Ljubljana, Slovenia marjana.merkac@gea-college.si

\section{Dalia Suša}

Faculty of Economics \& Business, University of Zagreb, Croatia dsusa@efzg.hr

\begin{abstract}
Although many researchers agree that environmental and personal characteristics are important for becoming an entrepreneur, it is still not clear if their influence is equally significant. Numerous authors have pointed out unresolved matters regarding the relationship among innovativeness, gender, and entrepreneurial intensions. The aim of this paper is to explore the impact of gender and country of origin in relation to entrepreneurial intentions and innovative cognitive style. Research was conducted using a sample of students majoring in information and communication technologies from Croatia and Slovenia. The results revealed the influence of gender, country, attitudes toward entrepreneurship, and innovative cognitive style on entrepreneurial intentions.
\end{abstract}

Key words: entrepreneurship, gender, innovation, cross-country, entrepreneurial intentions, ICT, Croatia, Slovenia

\section{Introduction}

Entrepreneurship is one of the main drivers of economic development and growth (Bjørnskov \& Foss, 2013). The significance of fostering entrepreneurial activities is confirmed by the continually increasing trend of various governmental and non-governmental organizations' actions towards promoting and encouraging entrepreneurship. Due to the importance of entrepreneurship, defining determinates of entrepreneurial intentions is crucial for future economic development.

Previous research regarding entrepreneurial intentions has revealed the impact of various factors. Lee, Wong, Der Foo, and Leung (2011) found that entrepreneurial intentions are affected by individuals' personal attraction to entrepreneurship, social norms among the micro and macro environments that shape beliefs and attitudes towards entrepreneurship, and perceived self-efficacy of an
ORIGINAL SCIENTIFIC PAPER

RECEIVED: NOVEMBER 2015

REVISED: DECEMBER 2015

ACCEPTED: DECEMBER 2015

DOI: 10.1515/ngoe-2016-0004

UDK: 658:001.895

JEL: L26

Citation: Pejić Bach, M., Merkač Skok, M., \& Suša, D. (2016). Determinants of Entrepreneurial Intentions in ICT Industry: Gender and country of origin perspective. Naše gospodarstvo/Our Economy, 62(1), 37-45. DOI: 10.1515/ ngoe-2016-0004

\section{NG OE}

NAŠE GOSPODARSTVO OUR ECONOMY

\begin{tabular}{l|l|l} 
Vol. 62 No.1 2016 \\
\hline
\end{tabular}

pp. 37-45 
individual as a future entrepreneur. However, the theory of entrepreneurship has still not shed light on the question as to whether environmental and personal characteristics are equally significant to entrepreneurial intentions.

Taking gender and country of origin into account, we considered if innovative cognitive style might have a significant influence on entrepreneurial intentions. This paper's aim is to investigate a gender approach to entrepreneurial intentions and innovative cognitive styles based on a cross-country survey carried out in Croatia and Slovenia. This work contributes to the existing body of knowledge regarding entrepreneurial intentions by providing confirmation of existing research. Moreover, this is the first study to investigate the influence of innovative cognitive style on information and communication technologies (ICT) students' entrepreneurial intentions in Croatia and Slovenia and can serve as a basis for future studies.

This paper consists of five parts. After the introduction, a literature review is presented on the topic, followed by a description of the methodology used. The fourth part gives the results of the employed logistic regressions, while at the end there is a short discussion with a conclusion emphasizing the most important findings and contributions of this paper.

\section{Literature Review}

No universally accepted definition for entrepreneur or entrepreneurship has achieved consensus (Carland, Carland, \& Carland, 2015; Klapper, Amit, \& Guillén, 2010). Gartner (1990) used the Delphi method to identify two main perspectives when trying to define entrepreneurship. The majority of Gartner's respondents (79\%) focused on entrepreneurship characteristics, while the rest (21\%) had entrepreneurship outcomes in their focus (Gartner, 1990). Summing up the various attempts to define entrepreneurship, it is the process and capacity of perceiving and exploiting good business opportunities in order to create business value while accepting risks in this regard (Dahalan, Jaafar, \&Rosdi, 2013; Landstrom, 2007; Sharif, 2015). By the same principle, an entrepreneur is an innovative and proactive person with a specific mind-set and vision who recognizes business possibilities, makes crucial decisions, and is willing to take risks in order to make a profit (McQuaid, 2002; Obembe, Otesile, \& Ukpong, 2014). In addition, some authors emphasize innovativeness as a very important characteristic of entrepreneurs (Drucker, 2014; Owoseni, 2014).

A number of studies have observed and investigated the personality of entrepreneurs. Numerous studies have demonstrated that entrepreneurship is a process that includes the identification and taking advantage of business chances, a predisposition for making decisions autonomously, risk taking, and innovativeness as well as a determination against competitors (Di Zhang \& Bruning, 2011; Lumpkin \& Dess, 1996). Mitchell et al. (2007) distinguished entrepreneurial cognition as a unique and special mixture of knowledge structures that help entrepreneurs efficiently use windows of opportunities by making adequate choices and decisions. Krueger, Reilly, and Carsrud (2000) indicated that entrepreneurial activities cannot be predicted by modelling only personal or situational factors and emphasized the importance of investigating entrepreneurial intentions in order to gain an understanding and prediction ability of entrepreneurial activity.

As previously mentioned, innovation plays an important role in entrepreneurial processes. Innovation and entrepreneurship complement and encourage each other, contribute to the success of an organization, and are both essential in enduring organizational sustainability in today's dynamic and turbulent global economy (Zhao, 2005). Moreover, a growing body of literature recognizes entrepreneurs as key enablers of making innovations available to the market; thus, the strong connection of entrepreneurship with innovation is evident (Szirmai, Naudé, \& Goedhuys, 2011). Individual innovative behaviour is influenced by many characteristics, such as individual problem-solving style, leadership skills, and work group relationships (Scott \& Bruce, 1994). Innovative cognitive style is a strongly ingrained style of decision-making, creativity, and problem solving (Beeftink, Van Eerde, Rutte, \& Bertrand, 2012). The Kirton Adaption-Innovation Inventory (KAI) is broadly used for measuring problem-solving cognitive style (Kirton, 2003; von Wittich \& Antonakis, 2011), which furthermore forms innovative behaviour (Beeftink et al., 2012).

The issue of gender influence on entrepreneurial intentions has been a matter of interest in numerous studies (Dahalan et al., 2013; Sasu \& Sasu, 2015; Wilson, Kickul, \& Marlino, 2007). Furthermore, a great number of studies have focused on barriers that women face along their path to becoming entrepreneurs (Harrison, Leitch, \& McAdam, 2015; Heilman \& Chen, 2003; Lynn \& Len, 2005). A recent study reported that women do not see themselves as highly capable in becoming and succeeding as entrepreneurs (Thébaud, 2010).

The use of ICT is an important part of entrepreneurial participation in the global economy, especially in creating a competitive advantage. Moreover, ICT usage helps female entrepreneurs equally take part in today's business world (Mathew, 2010). Martin and Wright (2005) pointed out the scarcity of literature regarding female ICT entrepreneurship 
and proposed further research on that topic. Based on the research conducted in ICT businesses, O'Connor, Hamouda, McKeon, Henry, and Johnston. (2006) reported a positive relationship between complementary skills in the co-entrepreneurial, mixed-gender founding teams and exploration of new business opportunities.

\section{Methodology}

\section{Research questions}

The research presented in this paper is based on the following research questions: (1) RQ1: Does the country of origin influence entrepreneurial intentions? (2) RQ2: Does the gender influence entrepreneurial intentions? (3) RQ3: Do attitudes towards entrepreneurship influence entrepreneurial intentions? (4) RQ4: Does innovative cognitive style influence entrepreneurial intentions? And (5) RQ5: What are the differences in gender regarding the influence of attitudes towards entrepreneurship and innovative cognitive style on entrepreneurial intention?

\section{Sample Description}

Our survey was conducted on a sample of students in an informatics study programmes of Croatian and Slovenian business and economic colleges ranging from second-year to graduate students. Student-based samples as well as cross-country samples have previously been used by other researchers in similar entrepreneurial intention studies (Ahmed et al., 2010; Mueller \& Thomas, 2001). Our sample consists of 541 respondents, of which $60.81 \%$ are Croatian students and $39.19 \%$ are Slovenian students. Table 1 presents the entrepreneurial intentions of respondents by their characteristics: country of origin, year of study, and gender. The majority of respondents at both the undergraduate (77.78\%) and graduate $(72.77 \%)$ levels of study are planned to start an enterprise. In addition, the majority of both male (89.29\%) and female (67.02\%) respondents planned to start an enterprise. The Chi-square revealed a statistically significant difference between the group of students planning to start an enterprise and those who were not, in terms of gender with a $p$-value below 0.01 .

\section{Research Instrument}

The research instrument was developed based on previous studies. The binomial dependent variable measured respondents' serious consideration of becoming an entrepreneur. Participants indicated agreement with the independent variables and constructs using a 7-point scale ( 1 = completely disagree, 7 = completely agree). There are two main groups of constructs. First, attitudes toward entrepreneurship together comprised the selected variable groups (personal attraction, social norms, and perceived self-efficacy) of entrepreneurial intentions (Liñan \& Chen, 2009). Second, cognitive abilities comprised innovative cognitive style (willingness to try, creative-original and opinion-leader, and ambiguities/ problems) measured by KAI (Goldsmith, 2011).

\section{Statistical Methods}

In order to check the validity of an instrument, a validity analysis was carried out. We have used items from existing

Table 1. Entrepreneurial Intentions

\begin{tabular}{|c|c|c|c|c|c|c|c|}
\hline \multirow{2}{*}{ Respondents' characteristics } & \multicolumn{2}{|c|}{ Total $(\mathrm{N}=541)$} & \multicolumn{2}{|c|}{$\begin{array}{l}\text { Planning to start an } \\
\text { enterprise }(N=400)\end{array}$} & \multicolumn{2}{|c|}{$\begin{array}{l}\text { Not planning to start an } \\
\text { enterprise }(N=141)\end{array}$} & \multirow[t]{2}{*}{ Chi-squar } \\
\hline & Freq. & $\%$ & Freq. & $\%$ & Freq. & $\%$ & \\
\hline \multicolumn{8}{|l|}{ I. Country } \\
\hline Croatia & 329 & $60.81 \%$ & 242 & $73.56 \%$ & 87 & $26.44 \%$ & \multirow{2}{*}{0.801} \\
\hline Slovenia & 212 & $39.19 \%$ & 158 & $74.53 \%$ & 54 & $25.47 \%$ & \\
\hline \multicolumn{8}{|l|}{ II. Year of study (ICT as major) } \\
\hline Undergraduate & 126 & $23.29 \%$ & 98 & $77.78 \%$ & 28 & $22.23 \%$ & \multirow{2}{*}{1.288} \\
\hline Graduate & 415 & $76.71 \%$ & 302 & $72.77 \%$ & 113 & $27.23 \%$ & \\
\hline \multicolumn{8}{|l|}{ III. Gender } \\
\hline Male & 168 & $31.05 \%$ & 150 & $89.29 \%$ & 18 & $10.71 \%$ & \multirow{2}{*}{$29.788^{* *}$} \\
\hline Female & 373 & $68.95 \%$ & 250 & $67.02 \%$ & 123 & $32.98 \%$ & \\
\hline
\end{tabular}

Note: (two-tailed) $* * p<0.01$

Source: Authors' survey 
studies, so we based the instrument content validity on that fact. For the sake of testing the reliability of using average values of items grouped into six variable groups, a reliability analysis was conducted using Cronbach's alpha coefficients. Feldt and Kim (2008) recommended using a cut-off value of 0.70 or higher for the Cronbach's alpha coefficient. As all of the calculated coefficients were higher than the cut-off value, we concluded that the item scales were internally consistent. A logistic regression was employed in order to investigate the relationship between dependent and independent variables. The validity of logistic regression models has been investigated using Nagelkerke $\mathrm{R}$ Square.

\section{Results}

Table 2 presents the results of logistic regressions conducted using entrepreneurial intention as the dependent variable based on the total sample. The results of the logistic regression employed in the total sample model revealed that entrepreneurial intentions are strongly affected by gender and personal attraction $(p<0.01)$ as well as social norms and creative-original $(p<0.05)$. Nagelkerke R Square shows that $46.1 \%$ of the variance in the response variable can be explained by the explanatory variables.

Table 3 presents the results of the logistic regression employed in the female-only sample and male-only sample.
When focusing on gender, only personal attraction affected entrepreneurial intentions in both the male $(p<0.05)$ and female $(p<0.01)$ samples. Male entrepreneurial intentions were also influenced by the country of origin and social norms $(p<0.10)$, whereas females are influenced by the creative-original factor $(p<0.05)$. On the other hand, in neither the female nor male samples did the year of study, perceived self-efficacy, willingness to try, or opinion-leader and ambiguities/problems factors have any significant influence on entrepreneurial intentions of the respondents. The male sample model explained $29.1 \%$ of the variance, while the female sample model explained $48.2 \%$ of the variance, as calculated by the Nagelkerke R Square.

Table 4 presents the results of the logistic regression according to the country of origin. In both the Croatian and Slovenian sample, gender and personal attraction had a strong impact on entrepreneurial intentions ( $p<0.05$ in the Croatian sample and $p<0.01$ in the Slovenian sample). Furthermore, the impact of social norms $(p<0.05)$ and creative-original $(p<0.10)$ group of constructs on entrepreneurial intentions was identified in the Croatian sample model. However, the year of study, perceived self-efficacy, willingness to try, and opinion-leader and ambiguities/problems constructs had no statistically significant impact on entrepreneurial intentions in either Croatia or Slovenia. The Croatian sample model explained $48.5 \%$ of the variance, while the Slovenian sample model explained $47.3 \%$ of the variance, as calculated by the Nagelkerke R Square.

Table 2. Logistic Regression Results with Entrepreneurial Intention as Dependent Variable, Total Sample Results

\begin{tabular}{lll} 
& & Total sample \\
\hline Respondent's characteristics & B & $P$-value \\
\hline Gender & & $0.000^{* * *}$ \\
\hline Year of Study & -1.365 & 0.842 \\
\hline Country & -0.065 & 0.499 \\
\hline Attitudes towards entrepreneurship & 0.193 & $0.000^{* * *}$ \\
\hline Personal Attraction & & $0.035^{* *}$ \\
\hline Social Norms & -0.798 & 0.320 \\
\hline Perceived Self-Efficacy & -0.186 & -0.114 \\
\hline Innovative cognitive style & & 0.653 \\
\hline Willingness to Try & -0.043 & $0.035^{* *}$ \\
\hline Creative-Original & -0.292 & 0.379 \\
\hline Opinion-Leader \& Ambiguities/Problems & -0.118 & $0.000^{* * *}$ \\
\hline Constant & 5.862 & \\
\hline Nagelkerke R Square & 0.461 & \\
\hline
\end{tabular}

Note: (two-tailed) $* p<0.10 ; * * p<0.05 ; * * * p<0.01$

Source: Authors' survey 
Table 3. Logistic Regression Results with Entrepreneurial Intention as Dependent Variable, According to Gender

\begin{tabular}{|c|c|c|c|c|}
\hline & \multicolumn{2}{|c|}{ Male } & \multicolumn{2}{|c|}{ Female } \\
\hline & B & $P$-value & B & $P$-value \\
\hline \multicolumn{5}{|l|}{ Respondents' characteristics } \\
\hline Year of Study & 0.100 & 0.871 & -0.213 & 0.592 \\
\hline Country & 1.646 & $0.073^{*}$ & -0.049 & 0.877 \\
\hline \multicolumn{5}{|l|}{ Attitudes towards entrepreneurship } \\
\hline Personal Attraction & -0.494 & $0.043^{* *}$ & -0.862 & $0.000^{* * *}$ \\
\hline Social Norms & -0.361 & $0.077^{*}$ & -0.148 & 0.140 \\
\hline Perceived Self-Efficacy & -0.309 & 0.345 & -0.117 & 0.358 \\
\hline \multicolumn{5}{|l|}{ Innovative cognitive style } \\
\hline Willingness to Try & 0.016 & 0.941 & -0.065 & 0.549 \\
\hline Creative-Original & 0.008 & 0.984 & -0.387 & $0.012^{* *}$ \\
\hline Opinion-Leader \& Ambiguities/Problems & -0.122 & 0.758 & -0.137 & 0.352 \\
\hline Constant & 1.921 & 0.289 & 6.799 & $0.000^{* * *}$ \\
\hline Nagelkerke R Square & 0.291 & & 0.482 & \\
\hline
\end{tabular}

Note: (two-tailed) * $p<0.10 ; * * p<0.05 ; * * * p<0.01$

Source: Authors' survey

Table 4. Logistic Regression Results with Entrepreneurial Intention as Dependent Variable, According to Country

\begin{tabular}{|c|c|c|c|c|}
\hline & \multicolumn{2}{|c|}{ Croatia } & \multicolumn{2}{|c|}{ Slovenia } \\
\hline & B & $P$-value & $\mathrm{B}$ & $P$-value \\
\hline \multicolumn{5}{|l|}{ Respondents' characteristics } \\
\hline Gender & -0.821 & $0.029^{* *}$ & -2.870 & $0.000^{* * *}$ \\
\hline Year of Study & -0.277 & 0.428 & 1.050 & 0.328 \\
\hline \multicolumn{5}{|l|}{ Attitudes towards entrepreneurship } \\
\hline Personal attraction & -0.807 & $0.000^{* * *}$ & -0.761 & $0.000^{* * *}$ \\
\hline Social Norms & -0.221 & $0.039^{* *}$ & -0.211 & 0.213 \\
\hline Perceived Self-Efficacy & -0.221 & 0.120 & -0.035 & 0.874 \\
\hline \multicolumn{5}{|l|}{ Innovative cognitive style } \\
\hline Willingness to Try & 0.013 & 0.912 & -0.153 & 0.375 \\
\hline Creative-Original & -0.342 & $0.066^{*}$ & -0.286 & 0.184 \\
\hline Opinion-Leader \& Ambiguities/Problems & -0.080 & 0.668 & -0.150 & 0.454 \\
\hline Constant & 6.464 & $0.000^{* * *}$ & 6.227 & $0.000^{* * *}$ \\
\hline Nagelkerke R Square & 0.485 & & 0.473 & \\
\hline
\end{tabular}

Note: (two-tailed) $* p<0.10 ; * * p<0.05 ; * * * p<0.01$

Source: Authors' survey

\section{Discussion and Conclusion}

The purpose of the current study was to investigate if gender, year of study, country of origin, attitudes towards entrepreneurship, and innovative cognitive style affected entrepreneurial intentions. After employing logistic regressions in order to analyse the results of the survey conducted among
Croatian and Slovenian ICT students, all previously stated research questions were answered.

The first research question (RQ1) asked if country of origin influences entrepreneurial intentions. The presented results revealed the influence of the country of origin on entrepreneurial intentions among male respondents. When referring 
to the second research question (RQ2), which was focused on the possible gender influence on entrepreneurial intentions, the results indicated the strong influence of gender on entrepreneurial intentions. Furthermore, the next two research questions (RQ3 and RQ4) dealt with the possible influence of attitudes towards entrepreneurship and innovative cognitive style on entrepreneurial intentions. These research results suggest that the selected variables of attitudes towards entrepreneurship and innovative cognitive style have a significant impact on entrepreneurial intentions. The last research question (RQ5) sought to determine the differences in gender regarding the influence of attitudes towards entrepreneurship and innovative cognitive style on entrepreneurial intention. The results of our research highlight the notable differences between male and female ICT students concerning their motivation towards becoming entrepreneurs. These differences are mostly evident in respondents' attitudes towards entrepreneurship in the form of social norms affecting males more than females and in cognitive abilities where females are more driven to start a new venture by being original and creative.

Based on the presented results, it could be concluded that males are more driven to become an entrepreneur by extrinsic motivation whereas females are more driven to start their own business by intrinsic motivation. The findings of this research align with some of the previous findings regarding the impact of gender on entrepreneurial intentions and gender differences among entrepreneurs (Dahalan et al., 2013; Di Zhang and Bruning, 2011; Gupta, Turban, Wasti, \& Sikdar, 2009; Mueller \& Thomas, 2001; Sasu \& Sasu, 2015; Thébaud, 2010). Entrepreneurial intentions are very strong among both Croatian and Slovenian students, with a statistically significant gender impact on students' entrepreneurial intentions.

As reported in Gupta et al. (2009), gender stereotypes regarding the perception of what an entrepreneur should be have a great impact on individuals' entrepreneurial intentions. Thus, the significant differences between males and females presented in this research are not surprising. These results could also be explained by the society's perception of entrepreneurship as a masculine domain, which influences females' concerns about if they could achieve success among male entrepreneurs. Nevertheless, ICT can help overcome this issue as many new possibilities are available for female entrepreneurs in terms of electronic businesses and virtual presence in which the gender distinction is often blurry. Khanka (2000) saw female entrepreneurs as confident, creative, and innovative women who are capable of achieving entrepreneurial success while balancing personal, family, and social life. Both males and females have a tendency to start or run a new business if they have the strong ability to solve problems and ambiguities as well as a high level of capacity to be the opinion leader of a group. On the other hand, Croats are still a traditionally raised society (Črpić, Sever, \& Mravunac, 2010), which may explain the strong impact of social norms on entrepreneurial intentions among Croatian respondents.

The investigation of gender influence points to the fact that women are conscious of different glass-ceilings and barriers facing female entrepreneurs, especially in the areas dominated by men, like technology and innovation (Ranga \& Etzkowitz, 2010). In addition, Kourilsky and Walstad (1998) indicated that men are much less aware of their knowledge insufficiencies and more self-assured in their abilities than women, which make females being more realistic about the matter. Based on these findings as well as ours, we could presume that education is highly important for females in terms of boosting their self-esteem as well as belief in success. In addition, females will probably count on their innovativeness and creativity in the process of becoming entrepreneurs as it is more likely that others will not be eager to cooperate due to the gender stereotypes. In their study, Martin and Wright (2005) indicated that the emphasis in ICT small businesses run by females is on innovation, which is consistent with results presented in this paper regarding the creative-original factor being statistically significant for entrepreneurial intentions among the female sample. However, Tominc and Rebrenik (2004) found that, despite the relatively high social and cultural support for female entrepreneurs, Slovenian women do not benefit from business opportunities, but are more likely to be forced into a business activity due to necessity. The Global Entrepreneurship Monitor's 2012 Women's Report highlighted the global recognition of female entrepreneurship, but also emphasized the importance of enabling supporting activities like providing better access to education and training activities as well as undertaking targeted efforts (Kelley, Brush, Greene, \& Litovsky, 2013). Another solution is given by Tominc and Rebrenik (2007) in the form of encouraging women to start a new business by the host society and not only family and friends (e.g., by lowering social services costs or offering niche funding loans for women entrepreneurs).

As this research was limited to students majoring in ICT in Croatian and Slovenian business and economic colleges, it was not possible to gain a large sample; thus, the sample size can be considered a limitation of the generalization of the results. Another limitation of this study is the uneven sample size regarding country of origin and the year of study. A larger part of the respondents were graduate students, which may have affected the high percentage of those planning to start an enterprise. Future research should repeat this study using larger and equal sample sizes in both countries and at the same level of studies. In addition, it would be interesting to include other countries in the region. 


\section{References}

1. Ahmed, I., Nawaz, M. M., Ahman, Z., Shaukat, M.Z., Usman, A., \& Wasim-ul-Rehman, A. N. (2010). Determinants of students' entrepreneurial career intentions. European Journal of Social Sciences, 16(2), 14-22.

2. Beeftink, F., Van Eerde, W., Rutte, C. G., \& Bertrand, J. W. M. (2012). Being successful in a creative profession: The role of innovative cognitive style, self-regulation, and self-efficacy.Journal of Business and Psychology, 27(1), 71-81. http://dx.doi.org/10.1007/s10869011-9214-9

3. Bjørnskov, C., \& Foss, N. (2013). How strategic entrepreneurship and the institutional context drive economic growth. Strategic Entrepreneurship Journal, 7(1), 50-69. http://dx.doi.org/10.1002/sej.1148

4. Carland Jr., J. W., Carland, J. A. C., \& Carland III, J. W. T. (2015). Self-actualization: The zenith of entrepreneurship. Journal of Small Business Strategy, 6(1), 53-66.

5. Črpić, G., Sever, I., \& Mravunac, D. (2010). Žene i muškarci: Egalitarnost na egzistencijalnoj i kolizija u svjetonazorskoj ravni. Društvena istraživanja, 19(1-2), 69-89.

6. Dahalan, N., Jaafar, M., \& Rosdi, S. A. M. (2013). Local community readiness in entrepreneurship: do gender differ in searching business opportunity. Procedia-Social and Behavioral Sciences, 91, 403-410. http://dx.doi.org/10.1016/j.sbspro.2013.08.437

7. Di Zhang, D., \& Bruning, E. (2011). Personal characteristics and strategic orientation: entrepreneurs in Canadian manufacturing companies.InternationalJournal ofEntrepreneurial Behavior \& Research,17(1),82-103.http://dx.doi.org/10.1108/13552551111107525

8. Drucker, P. (2014). Innovation and entrepreneurship. New York: Routledge.

9. Feldt, L. S., \& Kim, S. (2008). A comparison of tests for equality of two or more independent alpha coefficients. Journal of Educational Measurement, 45(2), 179-193. http://dx.doi.org/10.1111/j.1745-3984.2008.00059.x

10. Gartner, W. B. (1990). What are we talking about when we talk about entrepreneurship?. Journal of Business Venturing, 5(1), 15-28. http://dx.doi.org/10.1016/0883-9026(90)90023-M

11. Goldsmith, R. E. (2011). The validity of a scale to measure global innovativeness. Journal of Applied Business Research, 7(2), 89-97. http://dx.doi.org/10.19030/jabr.v7i2.6249

12. Gupta, V. K., Turban, D. B., Wasti, S. A., \& Sikdar, A. (2009). The role of gender stereotypes in perceptions of entrepreneurs and intentions to become an entrepreneur. Entrepreneurship Theory and Practice, 33(2), 397-417. http://dx.doi.org/10.1111/j.15406520.2009.00296.x

13. Harrison, R., Leitch, C., \& McAdam, M. (2015). Breaking glass: Toward a gendered analysis of entrepreneurial leadership. Journal of Small Business Management, 53(3), 693-713. http://dx.doi.org/10.1111/jsbm.12180

14. Heilman, M. E., \& Chen, J.J.(2003). Entrepreneurship as a solution: The allure of self-employment for women and minorities. Human Resource Management Review, 13(2), 347-364. http://dx.doi.org/10.1016/S1053-4822(03)00021-4

15. Kelley, D. J., Brush, C. D., Greene, P. G., \& Litovsky, Y. (2013). Global entrepreneurship monitor: 2012 women's report. Washington, MA: Center for Women's Leadership at Babson College.

16. Khanka, N. (2000). Entrepreneurship development. Mumbai: Himalaya Pub. House.

17. Kirton, M. J. (2003). Adaptation and innovation in the context of diversity and change. London: Routledge.

18. Klapper, L., Amit, R., \& Guillén, M. F. (2010). Entrepreneurship and firm formation across countries. In International differences in entrepreneurship (pp. 129-158). Chicago: University of Chicago Press. http://dx.doi.org/10.7208/chicago/9780226473109.003.0005

19. Kourilsky, M. L., \& Walstad, W. B. (1998). Entrepreneurship and female youth: Knowledge, attitudes, gender differences, and educational practices. Journal of Business Venturing, 13(1), 77-88. http://dx.doi.org/10.1016/S0883-9026(97)00032-3

20. Krueger, N. F., Reilly, M. D., \& Carsrud, A. L. (2000). Competing models of entrepreneurial intentions. Journal of Business Venturing, 15(5), 411-432. http://dx.doi.org/10.1016/S0883-9026(98)00033-0

21. Landstrom, H. (2007). Pioneers in entrepreneurship and small business research: 8 (International studies in entrepreneurship). New York: Springer Science \& Business Media.

22. Lee, L., Wong, P. K., Der Foo, M., \& Leung,A. (2011). Entrepreneurial intentions: The influence of organizational and individual factors. Journal of Business Venturing, 26(1), 124-136. http://dx.doi.org/10.1016/j.jbusvent.2009.04.003

23. Liñán, F., \& Chen, Y. W. (2009). Development and cross-cultural application of a specific instrument to measure entrepreneurial intentions. Entrepreneurship Theory and Practice, 33(3), 593-617. http://dx.doi.org/10.1111/j.1540-6520.2009.00318.x

24. Lumpkin, G. T., \& Dess, G. G. (1996). Clarifying the entrepreneurial orientation construct and linking it to performance. The Academy of Management Review, 21(1), 135-172. http://dx.doi.org/10.5465/AMR.1996.9602161568

25. Martin, L. M., \& Wright, L. T. (2005). No gender in cyberspace? Empowering entrepreneurship and innovation in female-run ICT small firms. International Journal of Entrepreneurial Behaviour \& Research, 11(2), 162-178. http://dx.doi.org/10.1108/13552550510590563

26. Mathew, V. (2010). Women in entrepreneurship in Middle East: Understanding barriers and use of ICT for entrepreneurship development. International Entrepreneurship and Management Journal, 6(2), 163-181. http://dx.doi.org/10.1007/s11365-010-0144-1

27. McQuaid, R. W. (2002). Entrepreneurship and ICT industries: support from regional and local policies. Regional Studies, 36(8), 909-919. http://dx.doi.org/10.1080/0034340022000012333

28. Mitchell, R. K., Busenitz, L. W., Bird, B., Gaglio, C. M., McMullen, J. S., Morse, E. A., \& Smith, J. B. (2007). The central question in entrepreneurial cognition research. Entrepreneurship Theory and Practice, 31(1), 1-27. http://dx.doi.org/10.1111/j.1540-6520.2007.00161.x 
29. Mueller, S. L., \& Thomas, A. S. (2001). Culture and entrepreneurial potential: A nine country study of locus of control and innovativeness. Journal of Business Venturing, 16(1), 51-75. http://dx.doi.org/10.1016/S0883-9026(99)00039-7

30. O'Connor, V., Hamouda, A., McKeon, H., Henry, C., \& Johnston, K. (2006). Co-entrepreneurial ventures: A study of mixed gender founders of ICT companies in Ireland. Journal of Small Business and Enterprise Development, 13(4), 600-619. http://dx.doi. org/10.1108/14626000610705778

31. Obembe, E., Otesile, O., \& Ukpong, I. (2014). Understanding the students' perspectives towards entrepreneurship. Procedia-Social and Behavioral Sciences, 145, 5-11. http://dx.doi.org/10.1016/j.sbspro.2014.06.005

32. Owoseni, O. O. (2014). The influence of some personality factors on entrepreneurial intentions. International Journal of Business and Social Science, 5(1), 278-284.

33. Ranga, M., \& Etzkowitz, H. (2010). Athena in the world of Techne: The gender dimension of technology, innovation and entrepreneurship. Journal of Technology Management of Innovation, 5(1), 1-13. http://dx.doi.org/10.4067/S0718-27242010000100001

34. Sasu, C., \& Sasu, L. (2015). Demographic determinant of the entrepreneurship intentions. The case of Romania. Procedia Economics and Finance, 20, 580-585. http://dx.doi.org/10.1016/S2212-5671(15)00111-2

35. Scott, S.G., \& Bruce, R.A.(1994). Determinants of innovative behavior:A path model of individual innovation in the workplace.Academy of management journal, 37(3), 580-607. http://dx.doi.org/10.2307/256701

36. Sharif, M. Y. (2015). Glass ceiling, the prime driver of women in entrepreneurship in Malaysia: A phenomenological study of women lawyers. Procedia-Social and Behavioral Sciences, 169, 329-336. http://dx.doi.org/10.1016/j.sbspro.2015.01.317

37. Szirmai, A., Naudé, W., \& Goedhuys, M. (2011). Entrepreneurship, innovation, and economic development. Oxford: Oxford University Press. http://dx.doi.org/10.1093/acprof:oso/9780199596515.001.0001

38. Thébaud, S. (2010). Gender and entrepreneurship as a career choice: Do self-assessments of ability matter?. Social Psychology Quarterly, 73(2), 288-304. http://dx.doi.org/10.1177/0190272510377882

39. Tominc, P., \& Rebernik, M. (2004). The scarcity of female entrepreneurship. Društvena istraživanja, 13(4-5), 779-802.

40. Tominc, P., \& Rebernik, M. (2007). Gender differences in early-stage entrepreneurship in three European post-socialist countries. Društvena istraživanja, 16(3), 589-611.

41. von Wittich, D., \& Antonakis, J. (2011). The KAI cognitive style inventory: Was it personality all along?. Personality and Individual Differences, 50(7), 1044-1049. http://dx.doi.org/10.1016/j.paid.2011.01.022

42. Wilson, F., Kickul, J., \& Marlino, D. (2007). Gender, entrepreneurial self-efficacy, and entrepreneurial career intentions: Implications for entrepreneurship education. Entrepreneurship Theory and Practice, 31(3), 387-406. http://dx.doi.org/10.1111/j.15406520.2007.00179.x

43. Zhao, F. (2005). Exploring the synergy between entrepreneurship and innovation. International Journal of Entrepreneurial Behaviour \& Research, 11(1), 25-41. http://dx.doi.org/10.1108/13552550510580825

\section{Authors}

Mirjana Pejić Bach, Ph.D., is a full professor of system dynamics, managerial simulation games, and data mining at the Department of Informatics in the Faculty of Economics and Business at the University of Zagreb. Her current research areas are simulation modelling, data mining, and web content research. She is the (co)author of a number of articles in international and national journals. She is actively engaged in a number of scientific projects and collaborates in several applied projects in the field of data mining, simulation modelling, and informatization.

Marjana Merkač Skok earned her Ph.D. in 1997 in management and organization sciences from the University of Maribor. Currently, she is a vice dean at the Faculty of Entrepreneurship at Gea College, Ljubljana, Slovenia. She also works as an independent expert for quality assurance in higher education in the EU. Before that, she worked as developer and expert in human resources and organizational development in industry and as a business consultant for management. She is involved in research about quality, system science, career management, and lifelong learning and training.

Dalia Suša is currently employed as a teaching and research assistant at the Department of Informatics, Faculty of Economics and Business, University of Zagreb, where she is also enrolled in a postgraduate doctoral study program. She graduated with a degree in managerial informatics from the Faculty of Economics and Business in Zagreb, where she wrote her master's thesis on unified communications, which earned the Dean's Award for Excellence. Her main research interests are digital literacy, unified communications, Web services, Web 2.0 technologies, and e-learning. 


\section{Determinante podjetniških namer v IKT po spolu in državi izvora}

\section{Izvleček}

Čeprav se mnogi raziskovalci strinjajo, da so okoljske in osebne karakteristike pomembne pri posameznikovi odločitvi, da postane podjetnik, še ni razjasnjeno, ali je vpliv teh karakteristik enako značilen. Številni avtorji opozarjajo na nerešena vprašanja, ki zadevajo povezavo med inovativnostjo, spolom in podjetniškimi namerami. Namen tega članka je raziskati vpliv spola in države izvora na povezanost podjetniških namer in inovativnega kognitivnega sloga. Raziskava je bila izvedena na vzorcu študentov IKT iz Hrvaške in Slovenije. Rezultati so pokazali vpliv spola, države, odnosa do podjetništva in inovativnega kognitivnega sloga na podjetniške namere.

Ključne besede: podjetništvo, spol, inovacija, meddržavne raziskave, podjetniške namere, IKT, Hrvaška, Slovenija 